\title{
Mirella Saulini
}

Bernardino Stefonio S.J. Un gesuita sabino nella storia del teatro. Rome: Espera, 2014. Pp. 146. Pb, 25 euros.

In May 1597, the relics of the Christian martyr Domitilla were moved to the church of ss. Achilleo e Nereo in a magnificent ceremony imagined in terms of an ancient Roman triumph. Domitilla was recast as a Flavian princess and the procession of her remains across the city was meant to surpass the classical precedents of her pagan imperial ancestors. A new inscription on the Arch of Titus reminded spectators that while the emperor might have avenged Christ by destroying Jerusalem, she, more gloriously than Titus, "had avenged Christ's death through giving her blood and life" (ipsa, sanguine, vitaque pro eius fide profusis gloriosius consecraverit; see Richard Krautheimer, "A Christian Triumph of 1597," in Essays in the History of Art presented to Rudolf Wittkower, eds. Douglas Fraser, Howard Hibbard and Milton J. Lewine [London: Phaidon, 1967], 174-78). Contemporaneously, across Italy and at the Collegium Romanum in particular, professors and students were recasting Senecan tragedy with Christian martyrs as ludi solemnes for performance at the beginning of the academic calendar or at the prize-giving ceremonies at the end of the school year.

Building upon her previous work on the late sixteenth-century Jesuit dramatists Stephanus Tuccius (Tuccio; 1540-1597) and Bernardinus Stephonius (Stefonio; 1562-1620) (Il teatro di un gesuita siciliano [Rome: Bulzoni, 2002]; “Il gran piacere che io sento in ragionare con gl'amici.' Lettere di Bernardino Stefonio (1560-1620) a Valentino Mangioni (1573-166o)," Archivium historicum Societatis Iesu 85 [2007]: 243-360; Stephanus Tuccius S.J., Christus Nascens, Christus Patiens, Christus Iudex [Rome: Bulzoni, 2011]), Mirella Saulini here further contextualizes the work of these important playwrights by providing a selection of original texts with facing (Italian) translations in a delightful, though slight, volume intended to showcase their writings.

The volume is divided in two parts. The first part, prefaced by a helpful bibliography and a general introduction outlining the role of drama within Jesuit education, documents Stefonio's life (including his important correspondence with Valentino Mangioni), before focusing on his famous tragedy Crispus (recently made available in an edition with commentary by Lucia Strappani and Luigi Trenti [Rome: Bulzoni, 1998]). The strength of the volume, however, lies in the second part, which provides an edition of selected scenes from the last acts of three different plays, thus allowing the development of the Jesuit martyr play to be traced and compared.

Arguing that Tuccio's Christus patiens (1569) provides the prototype for the martyr tragedy (Christ as the Rexmartyrum), Saulini here presents the exchange 
between Christ, Death, and the Centurion, whose conversion at the foot of the cross dramatizes the mystery of salvation and redemption, thus fulfilling the dictates of the Ratio studiorum, which emphasized the utility of drama in providing moral lessons.

With the added restrictions imposed upon school theatre by the new Ratio studiorum issued in 1591, historical drama appeared on the Jesuit stage. Stefonio's Crispus tragoedia (1597) is thus a Christianized version of the Phaedra story set at the court of the emperor Constantine. The passage chosen for inclusion here is the monologue spoken by the innocent Crispus as he is led to his place of execution. Constant in his faith and assured in his salvation, the road to martyrdom becomes a triumphal procession. Following the conventions of classical drama, the hero's death occurs off stage, but is here recounted by the Chorus in all its gory detail.

This convention is repeated in Stefonio's Flavia tragoedia (160o), which culminates in the death of three fictive members of the Flavian dynasty at the hands of the tyrannical emperor Domitian: the emperor's Christian cousin, Titus Flavius Clemens, and his two sons, Titus Flavius Vespasianus and Titus Flavius Domitianus. The play culminates in the feigned reconciliation of the emperor with his cousin, so that Domitian may observe the father's reaction when presented with his sons' decapitated heads. Roman Stoicism (exemplified in Seneca's philosophical works, available in a new edition by Marc Antoine Muret [1585]) converges triumphantly with Christian fortitude as Titus Flavius Clemens remains unflinching and is defiantly led off to his own execution. The difference between the brave Christian and his cruel pagan tormentors is brilliantly contrasted in the closing lines. While Clemens observes that death must come to all, but as a Christian he is secure in his salvation, his nemesis cynically commands his executioner to preserve his head too! (Nobis reserve, lictor, abreptum caput. Stephonius, Flavia, Act. v. 1211).

The plays are further supplemented by an edition of two of Stefonio's longer poetic works: Iuliana Villa ad Linternum descriptio [A description of the Villa Juliana at Literno] in 217 hendecasyllables and De suo pene naufragio [When I almost drowned] in 294 elegiacs, again with facing (Italian) translations. While new editions of inaccessible Jesuit poetry must be lauded, the lack of any substantial commentary or contextualization is a lost opportunity. The debt to earlier neo-Latin authors (Sannazaro springs to mind) could have been usefully explored, and reference to the work of Donatella Manzoli ("Ville e palazzo di Roma nelle descrizioni latine tra Rinascimento e Barocco," Studi Romani 56 [2008]: 109-66), would have located the first poem, at least, in a larger context. 
The volume concludes with a collection of twenty-four full-color images. As well as title pages, facsimiles of letters, and contemporary prints, this section includes fascinating plans of the elaborate choreography danced by the tragic choruses in Stefonio's Crispus, reminding us that the role of dance in Jesuit education has yet to be fully explored and understood.

Despite the limitations imposed by its format, this slim volume of texts and images provides a tantalizing glimpse of the sophisticated theatrical productions enjoyed at the Jesuit colleges, and the important role they played in the literary and moral education of the early Jesuits.

\section{Paul Gwynne}

The American University of Rome

p.gwynne@aur.edu

DOI 10.1163/22141332-00301005-24 